\title{
Sudden oak death management in Oregon tanoak forests
}

\author{
Ellen Michaels Goheen ${ }^{1}$, Alan Kanaskie ${ }^{2}$, Sarah Navarro ${ }^{2}$, and Everett Hansen ${ }^{3}$. \\ ${ }^{1}$ USDA Forest Service, Forest Health Protection, 2606 Old Stage Road, Central Point, OR 97502. \\ ${ }^{2}$ Oregon Department of Forestry, 2600 State Street, Salem, OR 97310. ${ }^{3}$ Department of Botany and Plant \\ Pathology, Oregon State University, Corvallis, OR 97331. Corresponding author: egoheen@fs.fed.us.
}

\begin{abstract}
Sudden oak death (SOD) caused by Phytophthora ramorum was first discovered in Oregon forests in July 2001. There appear to have been three separate introductions of P. ramorum into Oregon; in approximately 1998, 2008, and 2014. The most recent of these was the EU1 clonal lineage; all others were the NA1 clonal lineage. Since 2001 an interagency team has been attempting to eradicate the pathogen though a program of early detection (aerial and ground surveys, stream baiting) and destruction (herbicide treatment, felling and burning) of infected and nearby host plants; the program has evolved over time. Post-treatment monitoring indicates that although the pathogen has been eliminated from many of the sites, spread continues. From 2001 to 2015 the quarantine area expanded from $23 \mathrm{~km}^{2}$ to 1,333 $\mathrm{km}^{2}$, where it remains to date. Within a $145 \mathrm{~km}^{2}$ Generally Infested Area near the center of the quarantine area, most sites have not been treated and the disease has been allowed to intensify and spread. Where eradication treatments have stopped, canopy tanoak mortality increased from nearly zero to 87 percent during the 2012-2016 period. Managing sudden oak death in Oregon forests is challenging for many reasons and Oregon's program is likely to change in the future.
\end{abstract}

\section{Introduction}

Phytophthora ramorum Werres, De Cock \& Man in't Veld, the cause of sudden oak death (SOD), was first discovered in coastal southwest Oregon forests in July 2001 killing tanoak (Notholithocarpus densiflorus (Hook. \& Arn.) Manos, Cannon \& Oh), and causing shoot dieback and leaf-spotting of Pacific rhododendron (Rhododendron macrophyllum Don), and evergreen huckleberry (Vaccinium ovatum Pursh) (Goheen et al. 2002). The initial aerial survey and subsequent ground-checking identified five disease centers, ranging in size from 0.2 to 7.3 ha and totaling less than $16 \mathrm{ha}$, in a rural residential area, on private forest industry land, and on U.S. Department of Interior Bureau of Land Management, Coos Bay District (BLM) land. Archived aerial photographs revealed that tanoak mortality was present in at least one of the infested sites in 1998. Soon after the initial detection, an interagency team of plant pathologists from the Oregon Department of Agriculture (ODA), Oregon Department of Forestry (ODF), Oregon State University (OSU), and the U.S. Department of Agriculture Forest Service (FS) convened. Because the number of infestations was low and the area affected considered relatively small, we decided to attempt eradication of the pathogen by cutting and burning all infected and symptomatic host plants in the infested sites. We notified landowners, delimited eradication treatment areas, and acquired emergency funding. At that time, ODA also established an emergency quarantine area of $23 \mathrm{~km}^{2}$, prohibiting the movement of all host material from the regulated area unless treated (ORS 603-052-1230; ORS 2001). Since 2001, SOD management in Oregon has been a cooperative and collaborative effort of state and federal agencies along with numerous private landowners and stakeholders. From 2001 to 2015, approximately 2510 ha were treated. 
Phytophthora ramorum thrives under the wet conditions and mild temperatures common to the southwest Oregon coast (Hansen et al. 2008). In this region its major host is tanoak which is killed by the pathogen and serves as the primary source of inoculum throughout the year (Hansen et al. 2008; Reeser et al. 2009). Several other forest plant species are occasionally infected when growing within splash-distance of infected tanoak. These include Pacific rhododendron, evergreen huckleberry, Oregon myrtle (Umbellularia californica (Hook. \& Arn.) Nutt.), and cascara (Rhamnus purshiana DC). Tip dieback of seedling and sapling Douglas-fir (Pseudotsuga menziesii (Mirb.) Franco), coast redwood (Sequoia sempervirens (D. Don) Endl), and grand fir (Abies grandis (Douglas ex D. Don) Lindley is also observed during years with particularly wet springs when those species are growing directly beneath infected tanoak.

In Oregon, tanoak occurs on approximately 405,000 ha in four southwestern counties: Curry, Coos, Douglas, and Josephine (USDA Forest Inventory and Analysis 2008, unpublished). While not considered an important timber species, tanoak is valued by Native American communities in Oregon and California, and provides high nesting, roosting, and foraging value for a variety of wildlife species, and among other ecological values, supports high ectomycorrhizal diversity (Rizzo et al. 2005, Bergemann and Garbelotto 2006, Bowcutt 2013). Based on modeling incorporating host presence, particularly tanoak, and climate conducive to pathogen survival and spread, approximately 38 percent of Curry County is considered to be at very high or high risk for disease establishment, with progressively less very high or high risk area in Josephine, Coos, and Douglas Counties (Figure 1) (Václavik et al. 2010).



Figure 1. Sudden oak death risk map (left) and land ownership (right) in southwestern Oregon. Risk rating is influenced mostly by abundance of tanoak. 


\section{An overview of the Oregon Sudden Oak Death Management Program}

The Oregon SOD management program consists of quarantine, detection, delimitation of infested areas, eradication treatments, research, and monitoring.

\section{Quarantine}

Human-assisted spread of $P$. ramorum is managed through the designation of a SOD quarantine area under the authorities of the Oregon Department of Agriculture (ORS 603-052-1230) and the U.S. Department of Agriculture Animal Plant Health Inspection Service (7 CFR 301-92, CFR 2006). The state and federal quarantines regulate the intrastate and interstate movement of host plant material outside of the quarantine area. Oregon regulations, established in 2001, require infested sites on state and private lands to undergo eradication treatment and sets forth requirements for pest-free certification when moving host material from uninfested sites within the quarantine area to areas outside the quarantine. Pest-free designation in areas with no history of the pathogen is based on recent survey data; ODF or ODA staff must complete stream monitoring and ground surveys within three months of the date of the petition to the ODA. If no water sources are available for stream monitoring, aerial survey data may be substituted for stream monitoring data. A special permit is granted to designate an area pest-free when the ODA receives survey data showing that area is free of $P$. ramorum and diseases caused by $P$. ramorum. This designation lasts a maximum of 12 months from the conclusion of the required stream and vegetation monitoring surveys.

While federal land management agencies (FS and BLM) are not required by federal regulations to eradicate $P$. ramorum from infested sites, federal land managers conducted eradication treatments on all known infested sites on federal lands up until 2016.

\section{Detection}

Our detection efforts use ground, aerial and stream bait surveys. Ground-based detection and delimitation surveys near infested sites and in areas of high disease risk are conducted year-round. Using ground surveys we locate dead trees hidden from aerial observers by topography or by larger trees. Infected live trees and understory plants also are detected based on symptoms such as bleeding, stem lesions, wilting shoots, leaf spots, and branch dieback. Aerial surveys, both fixed-wing aircraft and helicopter, are conducted four times per year; the main surveys occur in July and October when current-year tanoak mortality is most visible. Aerial surveys focus on Curry County, dip slightly into northern California, and usually cover a cumulative area of at least 400 square $\mathrm{km}^{2}$ of forest per year; ground surveys cover 250 ha per year. We have recently incorporated the use of high resolution digital aerial imagery into the program as a means to augment aerial surveys. High-risk streams within and outside of the SOD quarantine area are targeted for stream baiting surveys during which host plant materials are periodically submerged in streams and then tested for the presence of P. ramorum. We deploy and collect stream baits at two-week to one-month intervals for a minimum of 8 to 10 months, beginning in late April. Sampling at as many as 64 bait stations per year is interrupted only by summer drought or winter floods. The area drained at the point of sampling has ranged in size from 8 to 3,634 ha and totaled a maximum of 32,192 ha in 2015 . Since 2001 we have placed stream baits at 177 different locations in Oregon.

\section{Eradication and slow-the-spread treatments}

When new infestations are found, we treat them by cutting and burning the infected tanoaks and other infected host plants on the site. Other exposed hosts, usually but not limited to tanoaks within an adjacent buffer of 15 to $300 \mathrm{~m}$, are also cut and burned. Buffer size depends on site location, its priority for slowing disease spread, and available funds. After the initial treatments in 2001, P. ramorum was occasionally isolated from tanoak sprouts. Based on this observation, herbicide treatments to reduce tanoak stump-sprouting were incorporated into treatment prescriptions when possible. Eradication treatment costs range from $\$ 5,000$ to $\$ 15,000$ per hectare depending on tanoak size and abundance, site 
accessibility, and terrain. When necessary or desired, treatment is followed by reforestation of conifer or other non-host species that reduce the risk of disease recurrence or spread. We monitor some sites for the persistence or recurrence of the pathogen with follow-up treatment to destroy residual or recurring infections.

Involved agencies have worked closely together to ensure that treatment prescriptions are similar across all ownerships and land allocations. Of the 2,510 ha treated in Oregon from 2001 to 2015, 1,950 ha are on state and private lands and 560 ha are on lands administered by the BLM and the FS.

Affected federally-administered sites have ranged from highly accessible and heavily used hiking trails to remote, relatively inaccessible sites with rugged terrain. We have temporarily closed to public access some popular hiking trails to facilitate treatments and monitoring. Treatments have occurred in many different federal land allocations including Inventoried Roadless Area, Late Successional Reserve, and Wild and Scenic River Corridor.

\section{Treatments using phosphite fungicides in Oregon}

In central coastal California, various phosphite products (phosphorous acid or phosphonate) have been shown to limit development of $P$. ramorum in coast live oak (Quercus agrifolia Nee) and tanoak when sprayed directly onto or injected into individual tree boles (Garbelotto et al. 2007, Garbelotto and Schmidt, 2009). In Oregon, only a few private landowners have used this approach to protect relatively small number of high-value trees. We evaluated aerial application of phosphite (Agri-fos ${ }^{\circledR} 400$ ) in Oregon in 2007 to 2009. The results demonstrated uptake of phosphite applied aerially to the canopy of a tanoak forest. The treatment resulted in reduced lesion size of Phytophthora spp. in bole inoculations, but had a small and inconsistent effect on lesion size in canopy twigs. Seedlings treated with aerially applied phophite were not protected from infection by P. ramorum when exposed to artificial or natural zoospore inoculum. Whether aerial applications of phosphite could significantly affect spread of sudden oak death in tanoak forests has yet to be determined (Kanaskie et al. 2011), but its widespread use is unlikely due to complications arising from land ownership patterns, diverse forest management objectives, steep terrain, very high stream density, and forest composition.

\section{Monitoring treatment efficacy}

Following eradication treatment, we have periodically surveyed sites to determine $P$. ramorum presence in soil or vegetation (Goheen et al. 2009, 2010, 2013). Briefly, circular plots (0.02 ha) were established in 2008 and 2009 around stumps of known infected trees at 145 sites that had received eradication treatments between 2001 and 2007. Similar sampling was done in 2010 on 143 plots. At each plot, 20, one-liter soil samples were collected, returned to the laboratory and baited with leaves of Viburnum sp. or Rhododendron macrophyllum. Presence of P. ramorum in the baits was determined by PCR analysis and culturing on Phytophthora-selective medium. Host vegetation was examined for symptoms of $P$. ramorum, and a minimum of five plant tissue samples were collected and returned to the laboratory to determine the presence of $P$. ramorum using an enzyme-linked immunosorbent assay (ELISA) to screen samples followed by PCR and culturing on Phytophthora-selective media. Based on these monitoring results a subsample of plots (68) were revisited in 2014 and sampled similarly.

Based on our sampling methods, eradication treatments appear to have eliminated disease from many infested sites. In the sample period 2008 to 2009, P. ramorum was not recovered from soil or vegetation on 74 (51 percent) of the 145 monitoring plots installed. Forty-seven plots ( 32 percent) yielded $P$.

ramorum from soils only (Goheen et al. 2013). The pathogen was present in soil and vegetation on 18 plots (12.5 percent), and on six plots (4.5 percent), P. ramorum was recovered from vegetation only. In the 2010 sampling, $P$. ramorum was not recovered from soil or vegetation on 90 ( 63 percent) of the 143 monitoring plots sampled. Thirty-six plots ( 25 percent) yielded $P$. ramorum from soils only, on ten plots (7 percent) the pathogen was present in soil and vegetation, and on seven plots (5 percent), P. ramorum 
was recovered from vegetation only. All positive vegetation samples were from tanoak in the 2008 to 2009 sampling period; most of the diseased material was collected from tanoak basal sprouts. Two $P$. ramorum-positive samples of Oregon myrtle were collected in the 2010 monitoring along with infected tanoak sprouts, see Table 1).

Table 1. Phytophthora ramorum recovery from monitoring plots on sites treated 2001-2008

\begin{tabular}{lccccc}
\hline $\begin{array}{l}\text { Sample } \\
\text { period }\end{array}$ & $\begin{array}{c}\text { P. ramorum } \\
\text { negative: soils } \\
\text { and vegetation }\end{array}$ & $\begin{array}{c}\text { P. ramorum } \\
\text { positive: soils } \\
\text { only }\end{array}$ & $\begin{array}{c}P \text {. ramorum } \\
\text { positive: soils and } \\
\text { vegetation }\end{array}$ & $\begin{array}{c}P \text {. ramorum } \\
\text { positive: } \\
\text { vegetation only }\end{array}$ & $\begin{array}{c}\text { Total } \\
\text { number of } \\
\text { plots }\end{array}$ \\
\hline $2008-2009$ & 74 & 47 & 18 & 6 & 145 \\
2010 & 90 & 36 & 10 & 7 & 143 \\
\hline
\end{tabular}

The likelihood of treatment success increased when treatments were completed soon after confirmation. 2014 monitoring data were also encouraging. P. ramorum was not detected on plots where it had not been detected in the past and where it did recur or persist in sprouting and seedling vegetation, it was present at very low levels (Goheen, unpublished data). There was also very little evidence of plant to plant spread on treated sites.

\section{Outcomes and future challenges}

From 2001 to 2010 the Oregon SOD program goal was to eradicate the pathogen. We modified treatments based on monitoring results. Eradication treatments eliminated disease from many infested sites. Despite monitoring results indicating successful eradication of $P$. ramorum from many individual treatment sites, SOD continued to spread slowly. By 2009, the disease had spread $8.5 \mathrm{~km}$ to the north, 1.9 $\mathrm{km}$ to the south, and $7.6 \mathrm{~km}$ to the east of the initial infected area. Northerly progression was most likely influenced by the direction of the prevailing wet-season wind (Kanaskie et al. 2011). Following a sharp increase in disease in 2010 and 2011, a result of leaving many infestations untreated, the program shifted goals from complete eradication to slowing spread. In 2013 the Oregon quarantine regulations were changed by establishment of a Generally Infested Area (GIA) in which eradication is no longer required by law on private and state lands. As a result, treatment of non-federal sites within the GIA has mostly abated. Priority is given to treating sites that occur outside of the GIA and close to the quarantine boundary. Through 2016, all new infestations outside the GIA have been cut and burned, but the size of the treatment area has varied in recent years based on available funds and site location.

Since 2001 the area under quarantine has expanded seven times: from $23 \mathrm{~km}^{2}$ in 2001 to $1,333 \mathrm{~km}^{2}$ in 2015, where it remains to date. Approximately $31 \%$ of the total area of Curry County is quarantined. More than half of the quarantine area is federally administered. The GIA has expanded four times and currently stands at $151 \mathrm{~km}^{2}$. From the initial infestations of 2001, the disease has been found a maximum distance of $28 \mathrm{~km}$ to the north, $12 \mathrm{~km}$ to the northeast along the Chetco river, and $11 \mathrm{~km}$ to the southeast along the Winchuck river. The maximum distance of natural spread (no evidence of human assistance) in any given year is estimated at 4.8 to $8 \mathrm{~km}$.

Within the GIA, eradication treatments were discontinued on most sites on private land since 2011, consequently the disease has been intensifying and spreading. Tanoak mortality now exists on several thousand hectares of forest, increasing the risk of wildfire and damage from falling trees (Figure 2). In a sample of 10 one-ha blocks, mortality of dominant and co-dominant tanoaks increased from nearly zero to an average of 87 percent from 2012 to 2016 (Figure 3). In contrast, on BLM land where eradication has been ongoing, disease intensification has been negligible. Despite the rapid rate of mortality in untreated areas, a few tanoaks are surviving and may provide an opportunity for resistance testing. 


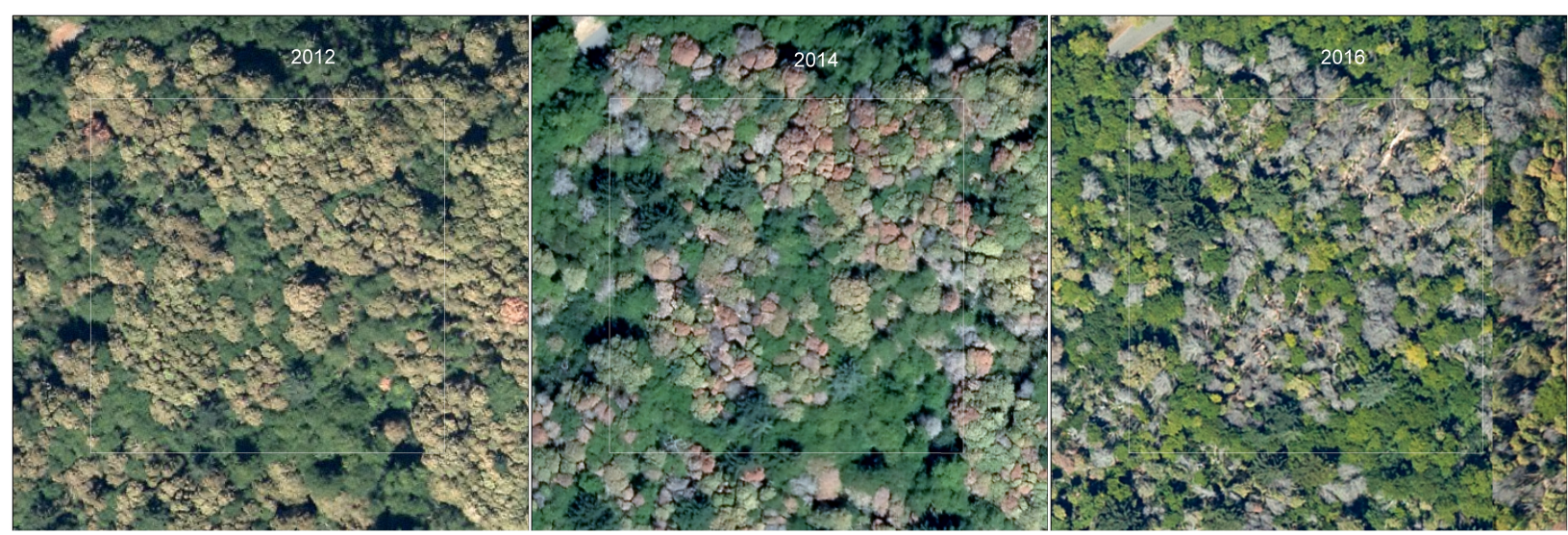

Figure 2. Mortality of dominant and co-dominant tanoaks killed by sudden oak death in a one-ha sample block inside the Generally Infested Area near Brookings, Oregon. High-resolution $(30 \mathrm{~cm})$ digital images taken in summer of 2012, 2014, and 2016 (left to right) showing the progression of tanoak from healthy (golden-green crowns) to recent mortality (orange-red crowns) to late-stage mortality (grey crowns). All overstory tanoaks died within the four year period; remaining green trees in 2016 are Douglas-fir and red alder (Alnus rubra Bong.).

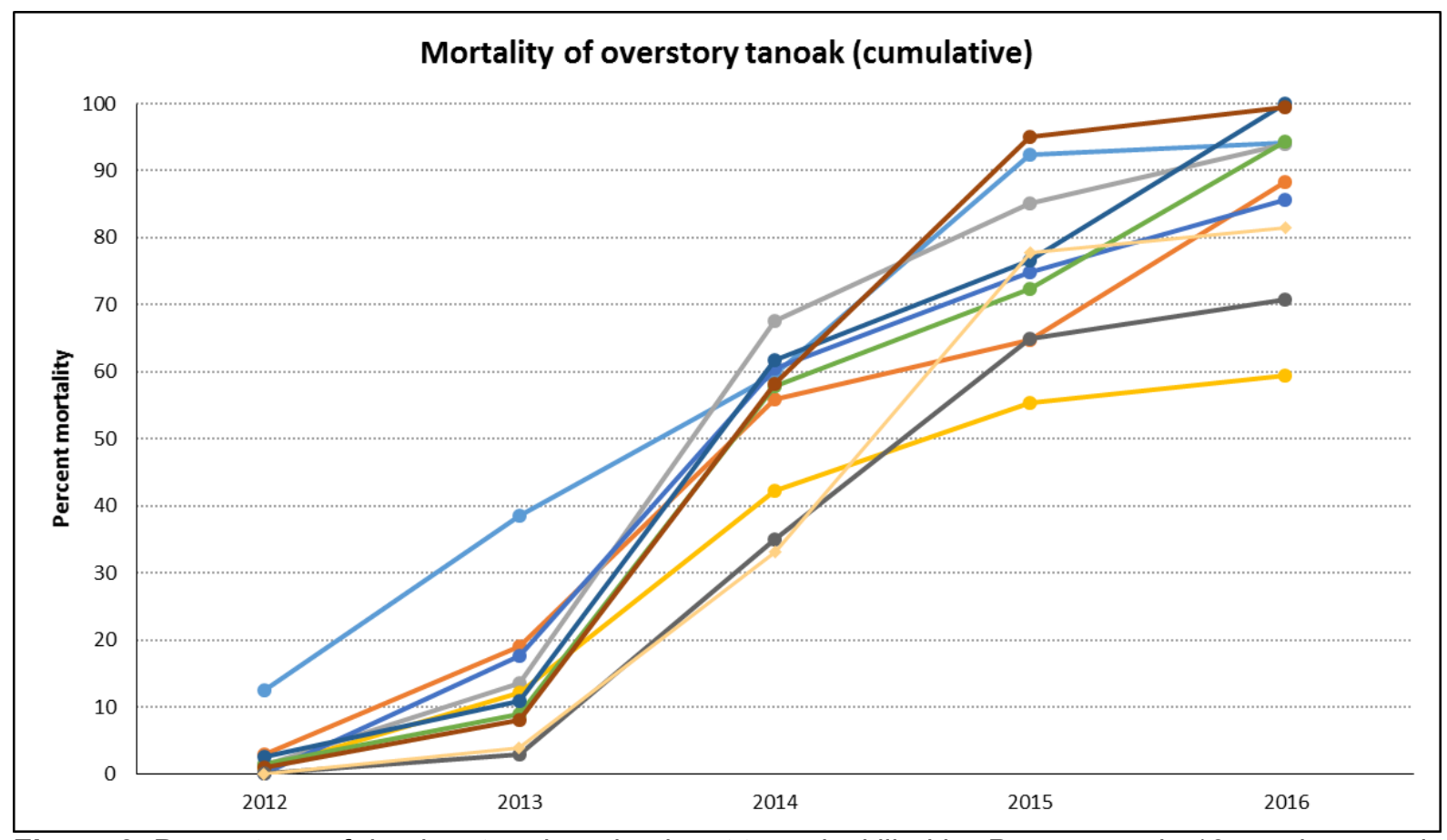

Figure 3. Percentage of dominant and co-dominant tanoaks killed by $P$. ramorum in 10 one-ha sample blocks located in infested areas that did not receive eradication treatments. Each line represents one sample block. Mortality was estimated from digital high-resolution $(30 \mathrm{~cm})$ color aerial imagery collected in July/August each year.

There appear to have been three separate introductions of $P$. ramorum into Oregon tanoak forests (Kamvar et al. 2015, Grunwald et al. 2016). Genetic analysis provides support for two introductions of the North American 1 (NA1) clonal lineage into Curry County from nurseries: one initial introduction into Curry County some time before detection of the first infected tanoak trees in 2001, followed by a second introduction from nursery stock into the Cape Sebastian/HunterCreek area (Kamvar et al 2015). 
Using aerial photography to identify dead tanoaks in the area, we estimate the pathogen was present as early as 1998 at sites associated with the initial detection, and was present in 2008 at the Cape Sebastian site, which was detected in 2012. In early 2015, we detected and confirmed the European 1 (EU1) clonal lineage of $P$. ramorum on a single tanoak tree located approximately one mile north of a small private nursery (now closed) near the Pistol River (Grunwald et al. 2016). Genotype comparison of the tanoak and nursery isolates suggests the nursery as the probable source for the forest infestation, and represents the third introduction. This is the first report of the EU1 lineage killing trees in a US forest. This finding is of particular concern because in Europe, the EU1 lineage kills or damages several conifer tree species and is considered more aggressive than the North American lineage (NA1). All host plants within approximately $130 \mathrm{~m}$ of the infected tree were cut and burned in 2015. In 2016, the EU1 lineage was detected for a second time, $0.8 \mathrm{~km}$ south of the EU1-infested tanoak found in 2015 . Of the 25 positive trees identified, two grand fir seedlings and 23 tanoaks are confirmed positive for EU1. High priority is being given to treatment at the EU1 sites.

To date, the cost of the SOD program in Oregon has been a little more than $\$ 18$ million. This includes all surveys, treatment, monitoring, and administration. It does not include research or the cost of regulatory compliance for timber companies and nurseries. Quarantines and regulatory compliance will impact economic gains of growing wood and plants in Oregon and will continue to present fiscal challenges for private enterprise and land management agencies without direct budget allocations for treatments (Hall 2009).

Eradication of Phytophthora ramorum is difficult because the pathogen produces aerial propagules and because there is a time lag between initial infection and the development of recognizable disease symptoms. Early detection and immediate felling, burning and herbicide treatment of host plants appear to reduce local intensification of the disease and the rate of spread in forests. Due to funding limits on the current slow-the-spread effort on non-federal lands and the establishment and expansion of the GIA (where there is no eradication effort on non-federal land), the amount of disease is increasing. The high level of inoculum in these areas increases the probability of long-distance spread naturally and by people. We believe this, along with favorable wet weather conditions for pathogen spread, has increased the number of new infestations at dispersal distances greater than four $\mathrm{km}$. It is reasonable to assume that rate of spread calculations that include the first ten years of the SOD management program will underestimate current and future spread. This trend also will increase the probability of spread of SOD into surrounding counties (Coos, Douglas and Josephine).

Procuring landowner permission for treatments and monitoring, working in densely populated areas with heavily fragmented ownerships, and working around utilities and other infrastructure are challenges facing state agency personnel trying to manage SOD. All agencies have difficulty acquiring adequate contractor capacity to treat multiple infestations simultaneously to complete work before the rainy (spread) period sets in. Likewise, seasonal fire restrictions prevent us from doing much work in the dry season, which would be advantageous from a disease spread standpoint.

We have developed tools to ensure as rapid a response to new infestations as possible. These include utilizing multi-year contracts for treatment with designated contractors and hiring local technical personnel dedicated to sudden oak death management. The FS and BLM have instituted programmatic consultation with federal regulatory agencies and streamlined environmental assessment procedures. But still, difficulty of detecting the disease in its earliest stages, access, air quality issues, fire restrictions, timing of funding, and timing treatments to avoid, when possible, disturbing nesting northern spotted owls and marbled murrelets, pose challenges to managing sudden oak death rapidly.

The future of the Oregon SOD program is uncertain. Agencies and stakeholders are considering several management alternatives including a) transitioning to living with the disease which would result in 
disease intensification and spread, the potential loss of tanoak on high risk sites, as well as wide-ranging social, economic, and ecological impacts, b) continuing our current slow-the-spread program as funded today, focusing on high priority sites (such as the EU1 sites and sites on the northern and eastern spread boundaries) and acknowledging that the disease is surpassing our capability to treat even high priority sites, c) continuing our slow-the-spread program but with adequate funding and infrastructure to rapidly and effectively treat all infestations with at least $100 \mathrm{~m}$ buffers, and d) containing SOD to Curry County by treating all known sites within Curry County as well as establishing an Action Zone at the Coos and Douglas County borders where additional surveys and monitoring would be done and contingency funds would be available for rapid response should the disease be found in these areas. Regardless of alternative, we will also need a strong research program to help us understand the potential impacts of the EU1 lineage relative to the NA1 lineage, to guide best management practices and treatment prescriptions, to support long-term tanoak resistance and gene conservation programs, and inform our strategy for addressing the next introduction of a non-native pathogen.

\section{Acknowledgements}

We extend appreciation to landowners in Curry County, especially the South Coast Lumber Co., for their cooperation. Funding for detection, monitoring, and eradication has been provided by: USDA Forest Service Pacific Northwest Region Forest Health Protection; USDA Forest Service Pacific Southwest Region Forest Health Protection; USDA Forest Service Forest Health Management; USDA Forest Service Pacific Southwest Research Station; USDI Bureau of Land Management; USDA Animal and Plant Health Inspection Service; Oregon State University; Oregon Department of Agriculture, and Oregon Department of Forestry.

\section{Literature cited}

Bergemann, S. E., Garbelotto, M. 2006. High diversity of fungi recovered from the roots of mature tanoak (Lithocarpus densiflorus) in northern California. Can. J. Bot. 84:1380-1394.

Bowcutt, F. S. 2013. Tanoak landscapes: tending a native American nut tree. Madrono 60(2):64-86.

Code of Federal Regulations of the United States of America. 2006. Pages 148-154 in: Domestic Quarantine Notices. Phytophthora ramorum. 7 CFR 301-92. February 14, 2002. U.S. Department of Agriculture, Animal Plant Health Inspection Service. 01-01-2006 edition.

Garbelotto M., Schmidt, D. J. 2009. Phosphonate controls sudden oak death pathogen for up to 2 years. Calif. Agric. 63(1):10-17.

Garbelotto M., Schmidt, D. J., Harnik, T.Y. 2007. Phosphite injections and bark application of phosphite + Pentrabark control sudden oak death in coast live oak. Arboriculture \& Urban For. 33(5):309-317.

Goheen, E. M., Hansen, E. M., Kanaskie, A., McWilliams, M. G., Sutton, W. 2002. Sudden oak death caused by Phytophthora ramorum in Oregon. Plant Dis. 86:441.

Goheen, E. M., Hansen, E. M., Kanaskie, A., Sutton, W., Reeser, P. 2009. Persistence of Phytophthora ramorum after eradication treatments in Oregon tanoak forests. Pages 173-176 in: Phytophthoras in Forests and Natural Ecosystems. Proceedings of the Fourth Meeting of the International Union of Forest Research (IUFRO) Working Party. Gen. Tech. Report PSW-GTR-221. Albany, CA. Pacific Southwest Research Station, Forest Service, U.S. Department of Agriculture.

Goheen, E. M., Kanaskie, A., Hansen, E., Sutton, W., Reeser, P., Osterbauer, N. 2010. Eradication effectiveness monitoring in Oregon tanoak forests. Pages 233-235 in: Proceedings of the Fourth Sudden Oak Death Science 
Symposium, Santa Cruz, CA. Frankel, S. J.; Kliejunas, J. T.; Palmieri, K. M., tech. coords. Gen. Tech. Rep. PSWGTR-229. Albany, CA. Pacific Southwest Research Station, Forest Service, U.S. Department of Agriculture.

Goheen, E. M., Kanaskie, A., Hansen, E., Sutton, W., Reeser, P., Osterbauer, N. 2013. Monitoring the effectiveness of Phytophthora ramorum eradication treatments in Oregon tanoak forests. Page 119 in: Proceedings of the Sudden Oak Death Fifth Science Symposium, Petaluma, CA. Frankel, S.J.; Kliejunas, J.T.; Palmieri, K.M.; Alexander, J.M. tech. coords. Gen. Tech. Rep. PSW-GTR-243. Albany, CA. Pacific Southwest Research Station, Forest Service, U.S. Department of Agriculture.

Grunwald, N., Larsen, M. M., Kamvar, Z. N., Reeser, P., Kanaskie, A. M., Hansen, E. M. Laine, J., Wiese, R. 2016. First report of the EU1 clonal lineage of Phytophthora ramorum on tanoak in an OR forest. Plant Dis.100(5):1024.

Hall, K. M. 2009. Cost analysis of quarantine zone size and control policy for an invasive forest pathogen. Master's thesis, Oregon State University. Retrieved 30 August 2010 from ScholarsArchive@OSU.

http://hdl.handle.net/1957/11964.

Hansen, E. M., Kanaskie, A., Prospero, S., McWilliams, M., Goheen, E. M., Osterbauer, N., Reeser, P., Sutton, W. 2008. Epidemiology of Phytophthora ramorum in Oregon tanoak forests. Can. J. For. Res. 38(5):1133-1143.

Kamvar Z. N., Larsen, M. M., Kanaskie, A. M., Hansen, E. M., Grünwald, 2015. Spatial and temporal analysis of populations of the sudden oak death pathogen in Oregon forests. Phytopathology 105(7):982-989.

Kanaskie, A., Hansen, E., Goheen, E., Osterbauer, N., McWilliams, M., Laine, J., Thompson, M., Savona, S., Timeus, H., Woosley, W., Sutton, W., Reeser, P., Schultz, R., Hilburn, D. 2011. Progress of the Phytophthora ramorum eradication programme in south-western Oregon forests, 2001-2009. N. Z. J. For. Sci. 41:S169-S175.

Kanaskie, A., Hansen, E. Sutton, W. Reeser, P. Choquette. C. 2011. Application of phosphonate to prevent sudden oak death in south-western Oregon tanoak (Notholithocarpus densiflorus) forests. N. Z. J. For. Sci. 41:S177-S187.

Kanaskie, A., Goheen, E. M., Hansen, E. M., Sutton, W., Reeser, P., Grunwald, N., Rhatigan, R., Wiese, R., Laine. J. 2014. Sudden oak death in Oregon forests: Recent disease intensification and spread, and changes to the management program. Pages 81-88 in: Proceedings of the Seventh Meeting of the International Union of Forest Research Organizations (IUFRO) Working Party S07.02.09: Phytophthoras in Forests and Natural Ecosystems. Sutton,W.; Hansen, E.M., tech. coords. November 10-14, 2014. Esquel, Chubut, Argentina.

Oregon Revised Statutes. 2001. Quarantine: Phytophthora ramorum. 603-052-1230, Division 52, Pest and Disease Control. Department of Agriculture.

Rizzo, D. M., M. Garbelotto, Hansen, E.M. 2005. Phytophthora ramorum, integrative research and management of an emerging pathogen in California \& Oregon forests. Annu. Rev. Phytopathol. 43:309-335.

USDA Forest Inventory and Analysis. 2008. Extract from Pacific Northwest Research Station, Forest Inventory and Analysis data (2001 - 2005) provided by Paul Dunham and David Azuma, unpublished.

Václavik, T., Kanaskie, A., Hansen, E. M., Ohmann, J. L., Meentemeyer, R. 2010. Predicting potential and actual distribution of sudden oak death in Oregon: Prioritizing landscape contexts for early detection and eradication of disease outbreaks. For. Ecol. Manage. 260(6):1026-1035. 